\title{
ANALISA KINERJA SISTEM DRAINASE TERHADAP PENANGGULANGAN BANJIR DAN GENANGAN BERBASIS KONSERVASI AIR DI KECAMATAN BOJONEGORO KABUPATEN BOJONEGORO
}

\author{
Bayu Wicaksono $^{1}$, Pitojo Tri Juwono ${ }^{2}$, Dian Sisinggih ${ }^{2}$ \\ ${ }^{1}$ Staf Pengawas Teknik Pengairan Dinas PU SDA Kabupaten Bojonegoro, Jawa Timur, Indonesia \\ ${ }^{2}$ Dosen Jurusan Teknik Pengairan, Fakultas Teknik, Universitas Brawijaya, Malang \\ Jurusan Pengairan Fakultas Teknik Universitas Brawijaya Jalan Mayjen Haryono 167 Malang Email: \\ 1bayu_pisp1@yahoo.com
}

\begin{abstract}
ABSTRAK: Kecamatan Bojonegoro rawan terjadi kantong genangan air hujan terutama saat musim penghujan disebabkan kecepatan aliran air hujan pada saluran drainase agak rendah karena kondisi topografi yang relatif datar. Terutama pada saat pada musim penghujan. Bojonegoro selain dipengaruhi oleh tingginya curah hujan yang relatif tinggi, kondisi topografi yang relative datar, perubahan tata guna lahan dan juga dipengaruhi oleh kurang memadainya sistem drainase yang ada. Dibutuhkan evaluasi sistem saluran drainase yang baik dan memadai baik terhadap kapasitas saluran eksisting serta penanganan berbasis konservasi air. Untuk menganalisanya dilakukan permodelan limpasan hujan kala ulang 5 tahun menggunakan software sewergems connect dengan membandingkan kondisi jaringan drainase eksisting dengan kondisi jaringan drainase sesudah penerapan pembangunan kolam retensi, sumur resapan dan modifikasi saluran. Perhitungan intensitas hujan menggunakan Metode Mononobe, diperoleh intensitas hujan durasi 6 jam dengan kala ulang 5 tahun. Hasil simulasi dengan hujan rancangan kala ulang 5 tahun menunjukkan 12 ruas saluran yang meluap. Dari hasil analisa kebutuhan metode penerapan secara konservatif untuk kolam retensi dibutuhkan dimensi sebesar $100 \mathrm{~m}$ x $50 \mathrm{~m}$ dengan kapasitas pompa $0,5 \mathrm{~m}^{3} / \mathrm{dtk}$, untuk sumur resapan yang dikombinasi dengan rain barrel dibutuhkan 577 buah, dengan dimensi penampang segi empat $1 \mathrm{~m} \times 1 \mathrm{~m} \times 2 \mathrm{~m}$ serta kapasitas rain barrel sebesar 750 liter, serta perbaikan dimensi saluran yaitu menambah lebar saluran di Jl. Panglima Polim, Jl. Dr. Sutomo dan Jl. Diponegoro.
\end{abstract}

Kata Kunci: debit limpasan hujan, drainase, kolam retensi, sumur resapan

ABSTRACT : Bojonegoro District is prone to flooding especially during the rainy season due
to the rapid flow of rain water on the drainage channel is rather low due to relatively flat
topography. Especially during the rainy season. Bojonegoro is influenced by relatively high
rainfall, relatively flat topography, changes in land use and is also influenced by the lack of
adequate drainage system. Necesary and adequate drainage system to be evaluation is
required both on existing channel capacity and water-based conservation. To analyze the
rainfall run-off model when re-use 5 years using software sewergems connect by comparing
the existing drainage network conditions with drainage network conditions after application of
the development of retention ponds, absorption wells and channel modifications. Calculation
of rain intensity using Mononobe Method, obtained rain intensity duration of 6 hours with re-
time 5 years. Simulation results with 5 year re-design rains show 12 overflowing channel
segments. From the result of requirement analysis of conservative application method for
retention pond required dimension of $100 m x$ mom with pump capacity 0,5 cu 3 sc, for
absorption wells combined with rain barrel needed 577 pieces, with rectangular section
dimension $1 m x 1 m x 2 m$ and capacity rain barrel of 750 liters, and improvement of channel 
dimension that is to increase channel width at Jl. Panglima Polim, Jl. Dr. Sutomo and Jl. Diponegoro.

Keyword : Run-off, Drainage, Retention Pond, Absorption well

Secara umum kondisi lahan di Kecamatan Bojonegoro berupa dataran dan agak rendah dibandingkan Kecamatan lainnya. Kondisi ini akan menyebabkan wilayah Kecamatan Bojonegoro rawan terjadi kantong genangan air hujan terutama saat musim penghujan disebabkan kecepatan aliran air hujan pada saluran drainase agak rendah karena kondisi topografi yang relatif datar serta adanya sedimentasi pada saluran drainase. Selain hal tersebut diatas kecamatan Bojonegoro berada disepanjang alur sungai Bengawan Solo pada dataran dengan ketinggian yang kurang lebih sama dengan Sungai Bengawan Solo (11,66 m) sementara daerah sekitarnya lebih tinggi menjadikan Kecamatan Bojonegoro berpotensi rawan banjir, terutama pada saat pada musim penghujan.

Kejadian banjir seringkali melanda wilayah di Kecamatan Bojonegoro, seperti diberitakan dalam website www.tempo.co.id tanggal 02 mei 2015 dengan hujan satu jam menyebabkan genangan di beberapa ruas jalan di kecamatan Bojonegoro dengan ketinggian genangan mencapai $50 \mathrm{~cm}$, atau di tahun 2016 diberitakan dalam website www.Berita Bojonegoro.com bulan Desember 2016 diberitakan bahwa drainase yang buruk picu genangan banjir di Kecamatan Bojonegoro. Sehingga dapat ditarik kesimpulan awal bahwa banjir di Kecamatan Bojonegoro selain dipengaruhi oleh tingginya curah hujan yang relatif tinggi, kondisi topografi yang relative datar, perubahan tata guna lahan dan juga dipengaruhi oleh kurang memadainya sistem drainase yang ada

Untuk mengatasi masalah genangan tersebut dibutuhkan jaringan drainasi yang memadai yang direncanakan secara detail dan menyeluruh, sesuai dengan konsep konservasi air. konsep dalam pengembangan konservasi air antara lain pembuatan sumur resapan, pembuatan kolam retensi dan rehabilitasi saluran. Untuk merencanakan pembangunan kolam retensi diperlukan analisis hidrologi untuk menentukan besarnya debit banjir rencana. Kemudian diperlukan data curah hujan untuk rencangan pemanfaatan air dan rancangan bangunan air adalah curah hujan rata-rata di seluruh daerah yang bersangkutan, (Sosrodarsono, 1993). Selain data tersebut, debit air kotor juga perlu direncanakan untuk memastikan jumlah air yang masuk ke dalam kolam retensi yang akan dibangun, pada perencanaan curah hujan pada suatu titik tertentu (Kusnaedi, 1995). Sedangkan Sumur resapan berfungsi untuk menampung dan meresapkan air hujan yang jatuh di atas permukaan tanah (Bisri dan Prastya, 2009). Perhitungan dan desain dari kolam retensi maupun sumur resapan disesuaikan pula berdasarkan Standart Nasional Indonesia yang berlaku (Departemen Pekerjaan Umum, 2010). Selain itu diperlukan pula untuk mengetahui berapa kebutuhan biaya yang diperlukan untuk menyelesaikan permasalahan yang terjadi, maka dihitung untuk kebutuhan akan bahan dan upah, serta biaya lain yang berhubungan dengan pelaksanaan bangunan atau proyek. (Bagian Pembangunan Kabupaten Bojonegoro, 2017)

Tujuan dari penelitian ini adalah untuk

1. Mengetahui gambaran/diskripsi sistem drainase yang menyebabkan genangan di wilayah kajian (ruas jalan Panglima Sudirman, jalan Panglima Polim, Jalan Pattimura, Jalan Mastrip, dan Jalan Diponegoro)

2. Mengetahui bagaimana upaya solusi serta metode penanganan drainase berbasis konservasi yang akan digunakan di daerah kajian

3. Mengetahui besarnya nilai rencana anggara biaya yang diperlukan dalam upaya penganggulangan genangan di lokasi kajian.

\section{METODE PENELITIAN Lokasi Studi}

Lokasi studi berada di Kecamatan Bojonegoro Kabupaten Bojonegoro dengan 3 (tiga) saluran drainase induk yang beroutlet pada sungai Bengawan Solo. Pembuatan peta tangkapan air didapat dengan menggunakan peta RBI dengan skala 1:5000, dengan titiktitik batas tangkapan air dikalibrasi menggunakan data hasil survey lapangan, sehingga didapat peta yang lebih akurat dan 
dapat dipertanggungjawabkan. Luas daerah Gambar 1. didapat seluas $6,12 \mathrm{~km}^{2}$. tangkapan air (DTA) di wilayah studi, menurut

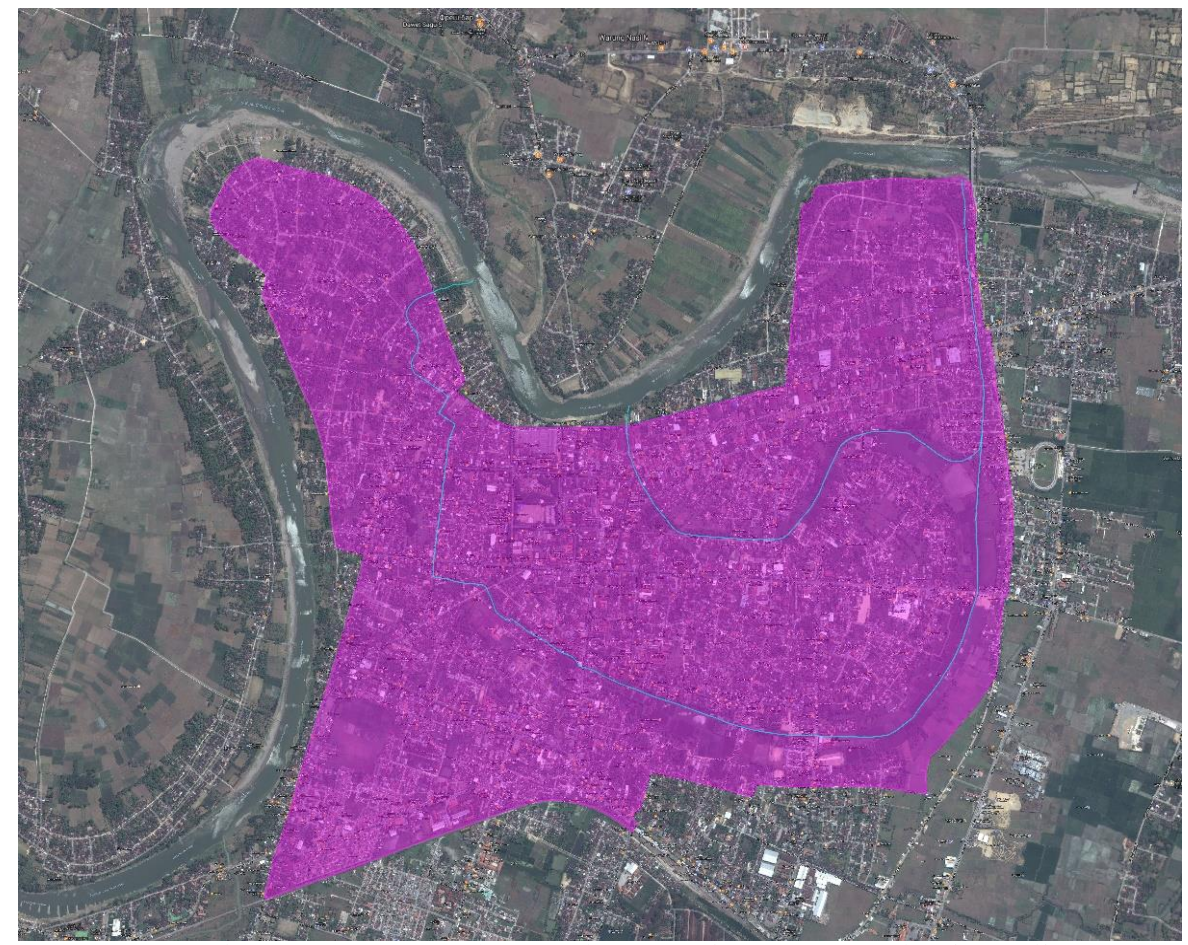

Gambar 1 Peta Daerah Tangkapan Air (DTA) Lokasi Studi Sumber: Hasil Analisa DTA Lokasi Studi

\section{Pengumpulan Data}

Metode pengumpulan data dalam penelitian ini menggunakan metode survey dan menggunakan data sekunder, yaitu data dikumpulkan dari instansi yang terkait. Jenis data yang dibutuhkan adalah:

1. Peta Topografi lokasi kajian, meliputi peta topografi, peta jaringan drainase eksisting, dan peta tata guna lahan.

2. Data dan Peta jaringan drainasi, berupa dimensi dan data saluran drainase.

3. Data curah hujan harian

4. Data harga satuan pekerjaan

5. Data tanah dan jenis tanah

\section{Pengolahan Data}

1. Melakukan analisis hidrologi :

- Menghitung curah hujan maksimum daerah dengan menggunakan cara polygon thiessen (Soemarto, 1999:11).

- Menghitung curah hujan rancangan dengan metode distribusi Log Pearson III lalu diuji horisontal dan vertikal yang bertujuan untuk mengetahui kebenaran hipotesa distribusi frekuensi Log Pearson III
2. Menganalis sistem drainasi untuk menentukan penyebab terjadinya genangan:

3. Merencanakan system drainase berbasis konservasi air

- Menghitung besarnya debit genangan yang terjadi di lokasi kajian

- Menghitung besarnya volume genangan yang terjadi di lokasi kajian Perhitungan volume genangan

- Menentukan alternatif metode antara lain : penempatan dan jumlah sumur resapan air hujan, kolam penampung, dan re-desain saluran eksisting

Metode penyelesaian dengan kolam penampung ditetapkan berdasarkan kondisi eksiting di lokasi studi dimana terdapat cekungan alami atau rawa, lokasi berada di sekitar terminal lama (Jl. Rajekwesi), Jl. Pattimura, sekitaran Jalan Setyabudi.

4. Merencanakan analisa rencana anggaran biaya yang ditimbulkan dalam upaya untuk mengatasi permasalahan di lokasi kajian. 



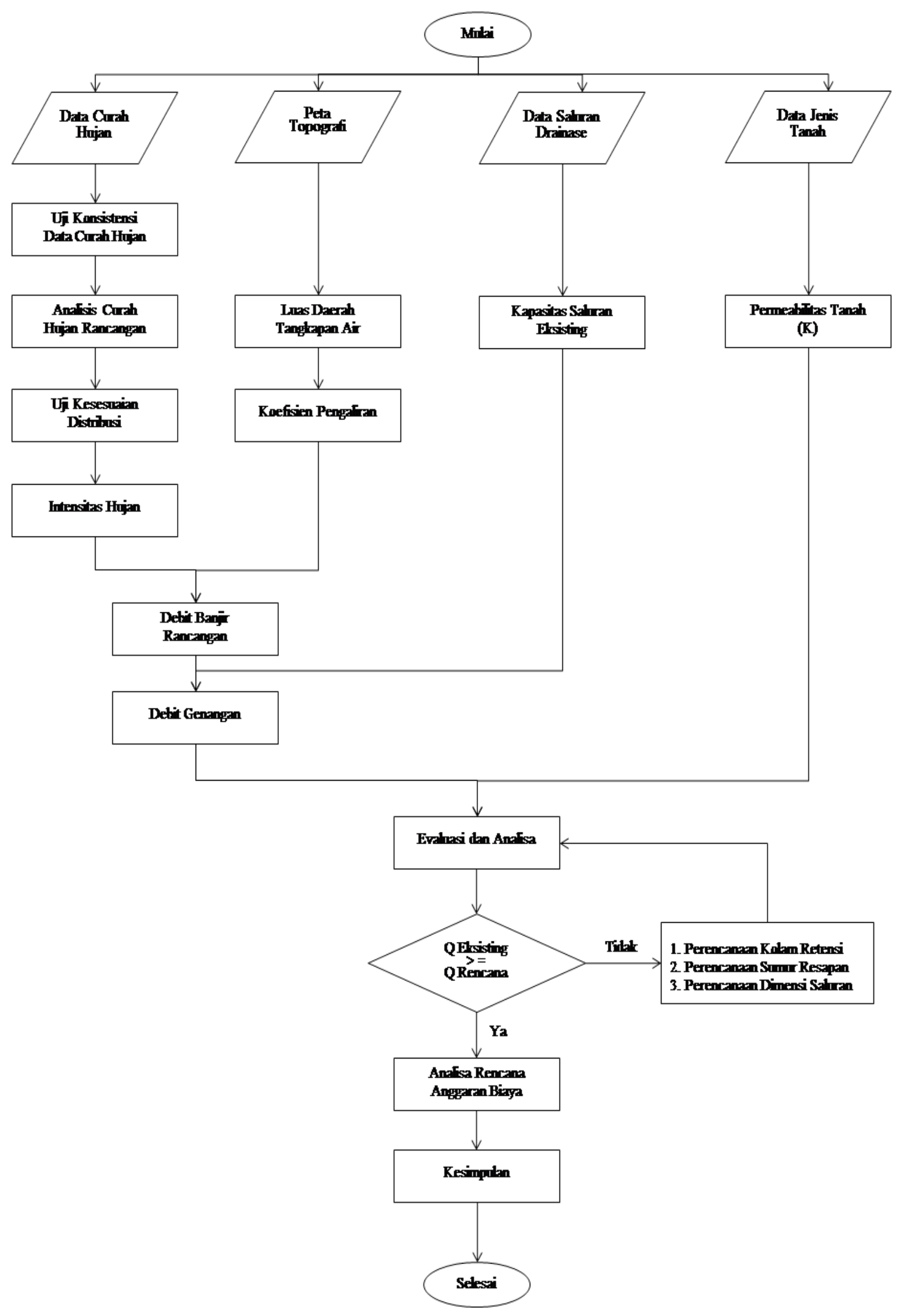

Gambar 2 Diagram Alir 


\section{HASIL DAN PEMBAHASAN Uji Kualitas Data Hujan}

Sebelum ditetapkan stasiun hujan yang akan digunakan untuk analisis, perlu dilakukan pengecekan data hujan dari pola hujan bulanan dan tahunan dengan dibandingkan data hujan stasiun di sekitarnya. Curah hujan tahunan rata-rata dari ke empat stasiun hujan tersebut adalah $1634 \mathrm{~mm}$. Dan curah hujan bulanan rata-rata maksimum sebesar $96 \mathrm{~mm}$ pada musim hujan. Pada analisis ini, uji kualitas data dilakukan dengan beberapa metode, antara lain: Pengujian Outlier, Lengkung Massa Ganda dan Metode RAPS.

\section{Curah Hujan Rerata Daerah}

Curah hujan rata-rata daerah di dihitung dengan mengalikan curah hujan harian maksimum tahunan yang terjadi pada hari yang sama pada masing-masing stasiun dengan koefisien Thiessen, setelah dijumlahkan maka diambil yang maksimum dimana nilai tersebut merupakan curah hujan daerah harian maksimum tahunan yang akan dipakai sebagai dasar perhitungan.

Tabel.1 Curah Hujan Rerata

\begin{tabular}{|r|r|r|r|r|}
\hline \multirow{2}{*}{ No. } & \multirow{2}{*}{ Tahun } & \multicolumn{2}{|c|}{ Sta. Bojonegoro } & \multirow{2}{*}{$\begin{array}{c}\text { Curah } \\
\text { Hujan } \\
\text { Rerata }\end{array}$} \\
\hline 1 & 2002 & 66,00 & $100 \%$ & 66,00 \\
\hline 2 & 2003 & 125,00 & $100 \%$ & 125,00 \\
\hline 3 & 2004 & 113,00 & $100 \%$ & 113,00 \\
\hline 4 & 2005 & 115,00 & $100 \%$ & 115,00 \\
\hline 5 & 2006 & 112,00 & $100 \%$ & 112,00 \\
\hline 6 & 2007 & 95,00 & $100 \%$ & 95,00 \\
\hline 7 & 2008 & 105,00 & $100 \%$ & 105,00 \\
\hline 8 & 2009 & 85,00 & $100 \%$ & 85,00 \\
\hline 9 & 2010 & 149,00 & $100 \%$ & 149,00 \\
\hline 10 & 2011 & 61,00 & $100 \%$ & 61,00 \\
\hline 11 & 2012 & 99,00 & $100 \%$ & 99,00 \\
\hline 12 & 2013 & 133,00 & $100 \%$ & 133,00 \\
\hline 13 & 2014 & 76,00 & $100 \%$ & 76,00 \\
\hline 14 & 2015 & 57,00 & $100 \%$ & 57,00 \\
\hline
\end{tabular}

Sumber: Hasil Perhitungan

\section{Distribusi Frekuensi Hujan}

Tabel 2 Hasil Kesesuaian Distribusi Frekwensi Berdasarar Parameter Statistik

\begin{tabular}{|c|c|l|l|l|}
\hline No. & Metode & \multicolumn{1}{|c|}{ Syarat } & \multicolumn{1}{c|}{ Hasil } & \multicolumn{1}{c|}{ Keterangan } \\
\hline \multirow{2}{*}{1} & \multirow{2}{*}{ Gumbel } & $\mathrm{Cs}>1.1395$ & $\mathrm{Cs}=0,00$ & Tidak memenuhi \\
\cline { 3 - 5 } & & $\mathrm{Ck}>5.4$ & $\mathrm{Ck}=-0,78$ & Tidak memenuhi \\
\hline \multirow{2}{*}{2} & \multirow{2}{*}{ Normal } & $-0.05<\mathrm{Cs}<0.05$ & $\mathrm{Cs}=0,00$ & Tidak memenuhi \\
\cline { 3 - 5 } & & $2.7<\mathrm{Ck}<3.3$ & $\mathrm{Ck}=-0,78$ & Tidak memenuhi \\
\hline 3 & Log Pearson Type III & Tidak ada batasan & & Memenuhi \\
\hline 4 & Log Normal & $2.7<\mathrm{Ck}<3.3$ & $\mathrm{Cs}=0,00$ & Tidak memenuhi \\
\hline
\end{tabular}

Sumber: Hasil Perhitungan

Uji Kesesuaian Distribusi

Tabel 4 Rekapitulasi Hasil Pengujian Kesesuaian Distribusi Frekuensi Chi-Square

\begin{tabular}{|c|l|c|r|c|}
\hline \multirow{2}{*}{ No. } & \multicolumn{1}{|c|}{ Metode Distribusi } & \multicolumn{2}{|c|}{$\begin{array}{c}\text { Uji Chi-Square }\left(\mathrm{X}^{2} \text { hitung }<\mathrm{X}^{2}\right. \\
\text { kritis })\end{array}$} & \multirow{2}{*}{ Hasil Uji } \\
\cline { 3 - 4 } & & $\mathrm{X}^{2}$ hitung & $\mathrm{X}^{2}$ kritis & \\
\hline 1 & Distribusi Gumbel & 2,43 & $4,61(\alpha=0,01)$ & $\begin{array}{c}\text { Diterima } \\
\text { Diterima }\end{array}$ \\
\hline 2 & Distribusi Log Pearson III & 0,29 & $4,99(\alpha=0,05)$ & $\begin{array}{c}\text { Diterima } \\
\text { Diterima }\end{array}$ \\
\hline 3 & Distribusi Normal & 1,71 & $5,99(\alpha=0,01)$ & Diterima \\
& & & $5,99(\alpha=0,01)$ & Diterima \\
\hline 4 & Distribusi Log Normal & 1,00 & $4,61(\alpha=0,01)$ & Diterima \\
& & & $5,99(\alpha=0,05)$ & Diterima \\
\hline
\end{tabular}

Sumber: Hasil Perhitungan

Pengujian dilakukan dengan membandingkan probabilitas tiap data,antara sebaran empiris dan sebaran teoritis. Berdasarkan Uji
Frekuensi Hujan dan Uji kesesuaian Distribusi yang telah dilakukan, maka untuk selanjutnya perhitungan evaluasi kapasitas tampungan 
saluran drainase eksisting akan menggunakan curah hujan rancangan metode Log Pearson Tipe III.

\section{Intensitas Curah Hujan}

Biasanya intensitas hujan dihubungkan dengan durasi hujan jangka pendek. Perhitungan intensitas hujan kala ulang 5 tahun sebagai berikut :

$$
\begin{aligned}
\mathrm{I} & =\frac{R 24}{24}\left(\frac{24}{t c}\right)^{m} \\
& =\frac{123,17}{24}\left(\frac{24}{6}\right)^{2 / 3} \\
& =12,94 \mathrm{~mm} / \mathrm{jam}
\end{aligned}
$$

Tabel. 6 Perhitungan intensitas hujan

\begin{tabular}{|c|c|c|c|c|c|c|c|}
\hline \multirow{2}{*}{ No. } & \multirow{2}{*}{ Kala Ulang } & \multicolumn{7}{|c|}{ Intensitas Hujan } \\
\cline { 3 - 8 } & $\begin{array}{c}\text { Durasi 1 } \\
\text { Jam }\end{array}$ & $\begin{array}{c}\text { Durasi 2 } \\
\text { Jam }\end{array}$ & $\begin{array}{c}\text { Durasi 3 } \\
\text { Jam }\end{array}$ & $\begin{array}{c}\text { Durasi 4 } \\
\text { Jam }\end{array}$ & $\begin{array}{c}\text { Durasi 5 } \\
\text { Jam }\end{array}$ & $\begin{array}{c}\text { Durasi 6 } \\
\text { Jam }\end{array}$ \\
\hline 1 & 2 & 33,91 & 21,35 & 16,29 & 13,45 & 11,59 & 10,26 \\
\hline 2 & 5 & 42,75 & 26,92 & 20,54 & 16,96 & 14,61 & 12,94 \\
\hline 3 & 10 & 47,68 & 30,03 & 22,92 & 18,91 & 16,30 & 14,43 \\
\hline 4 & 25 & 53,12 & 33,45 & 25,53 & 21,07 & 18,16 & 16,08 \\
\hline 5 & 50 & 56,69 & 35,70 & 27,24 & 22,49 & 19,38 & 17,16 \\
\hline
\end{tabular}

Sumber : Perhitungan

\section{Analisis Evaluasi Kapasitas Saluran Drainase \\ Evaluasi kapasitas saluran drainase dilakukan dengan simulasi menggunakan software Benley sewergems connect. Berdasarkan}

debit banjir kala ulang 5 tahun, yaitu sebesar $12,94 \mathrm{~m}^{3} / \mathrm{dt}$. Berikut disajikan Skema hasil simulasi dengan kondisi sistem drainase eksisting (Gambar 4)

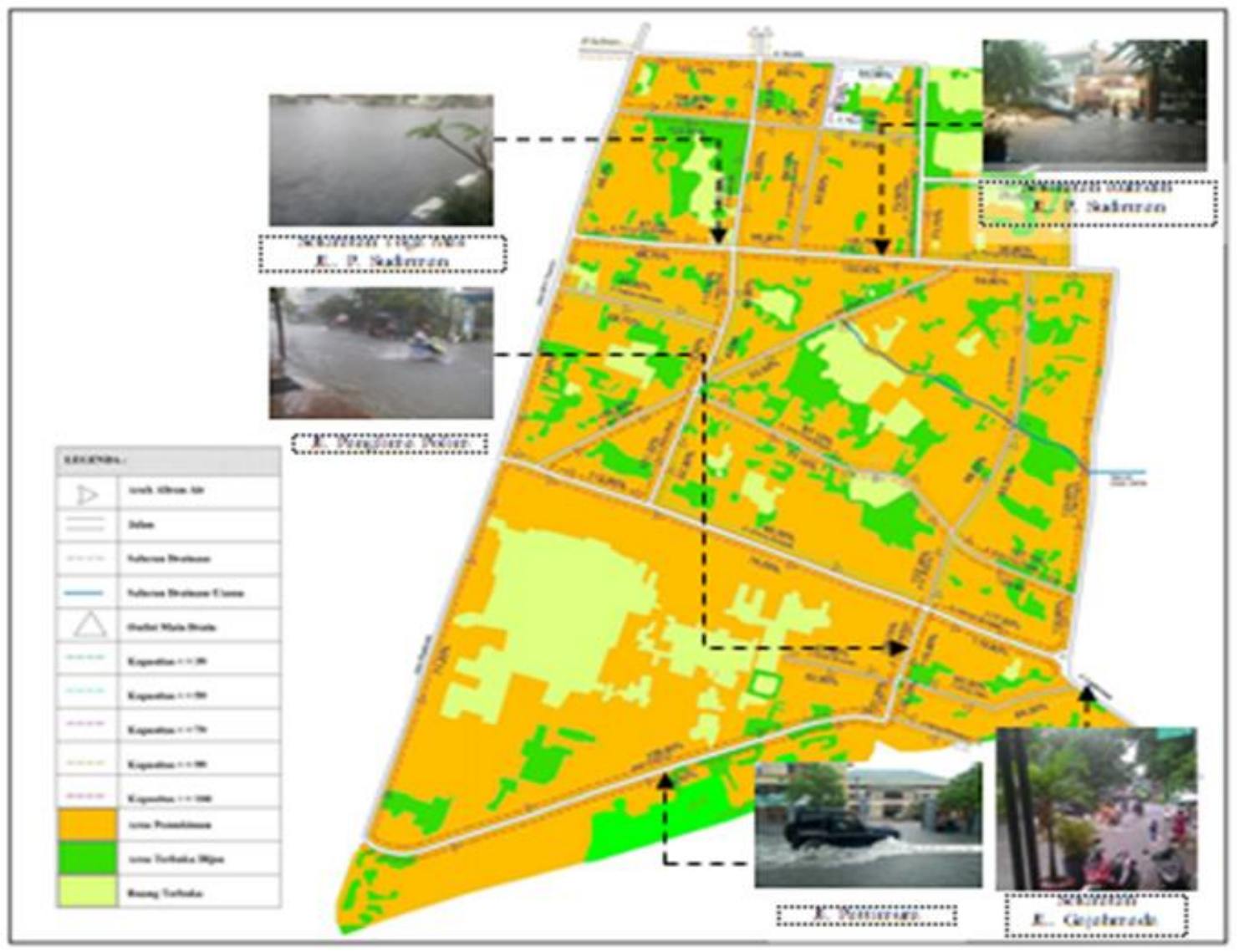

Gambar 4 Skema Kondisi Sistem Drainase Eksisting Sumber: Hasil Analisa Benley Kondisi Eksisting 


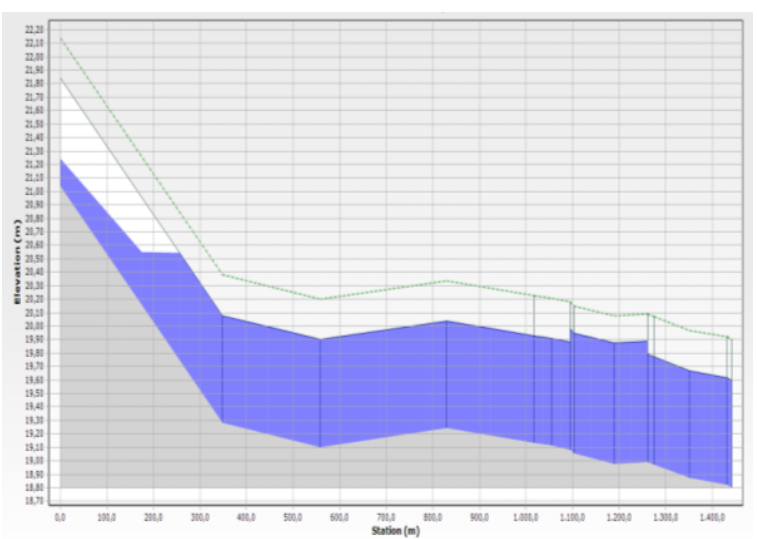

Saluran Pattimura Ki - P. Polim Ki - Dr. Sutomo

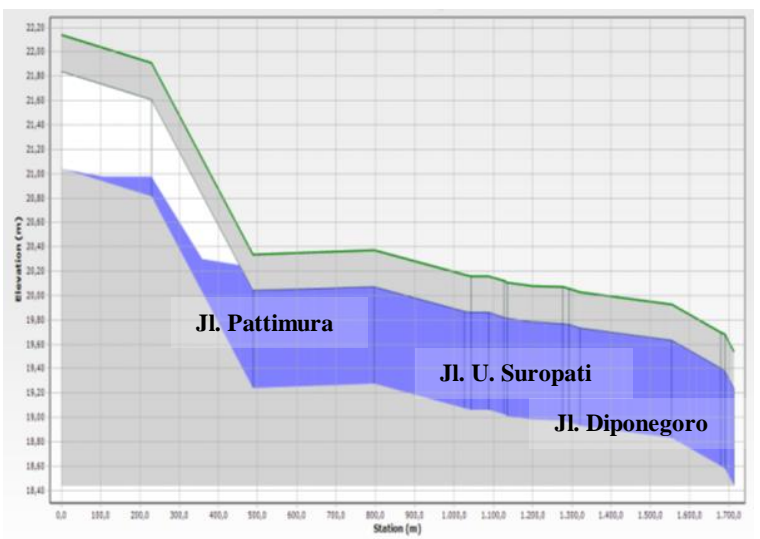

Saluran Pattimura - Untung Suropati - Diponegoro

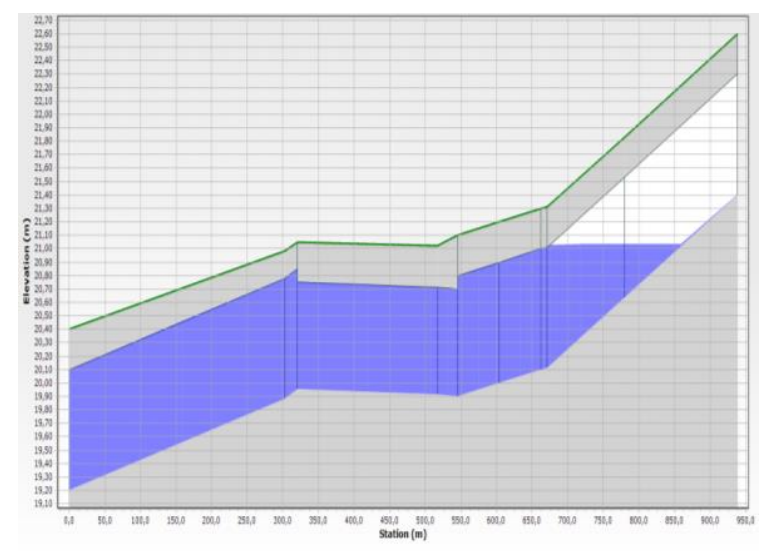

Saluran Gg. Hartono - Mastrip - MH. Thamrin

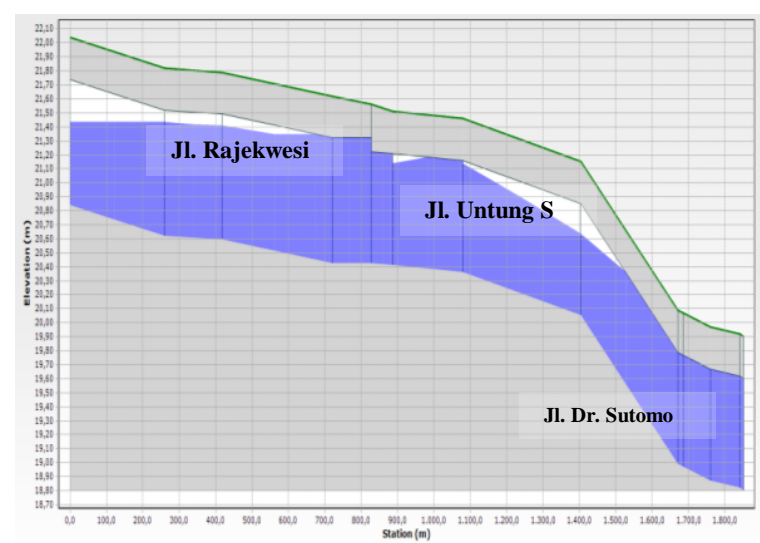

Saluran Rajekwesi - Untung Suropati - Dr. Sutomo

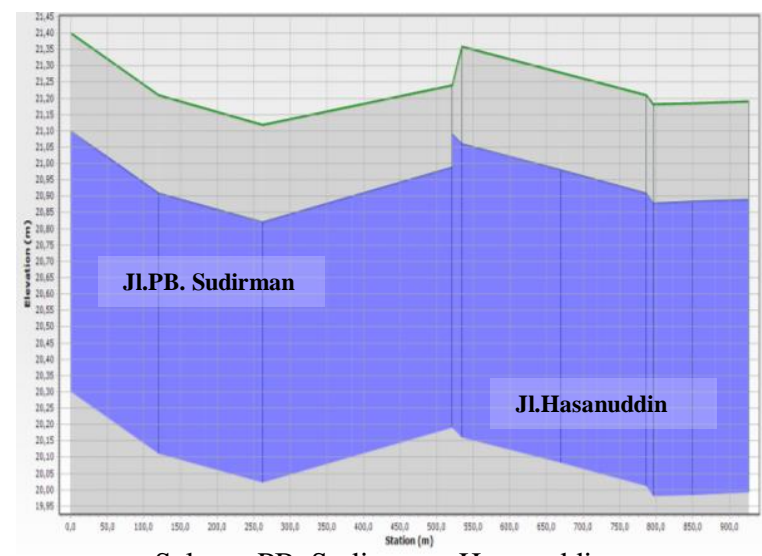

Saluran PB. Sudirman - Hasanuddin

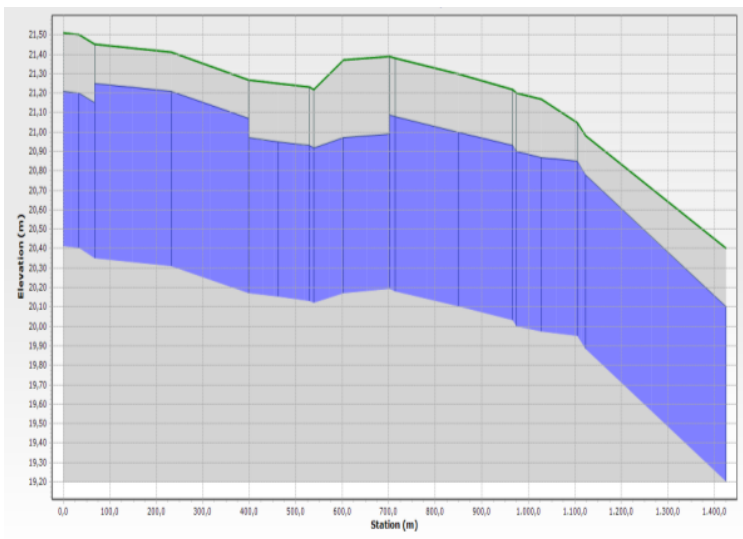

Saluran Untung Suropati - Kyai Sulaiman Setyabudi - Hasanuddin - Gg Hartono

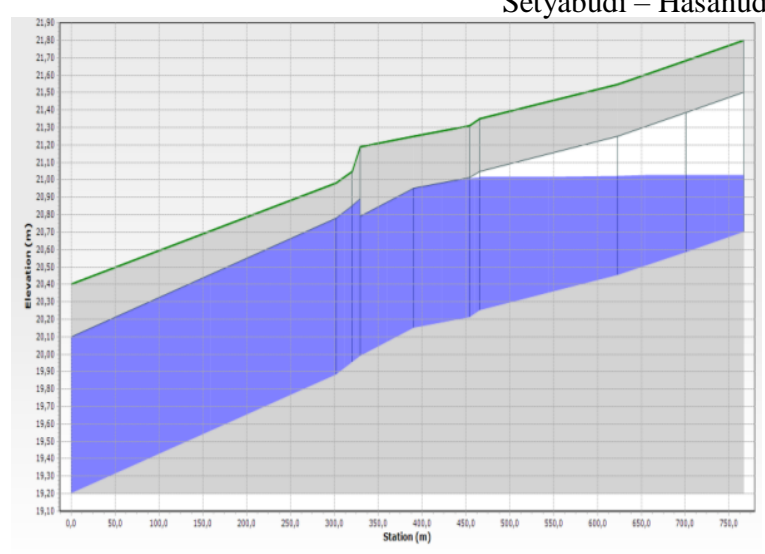

Saluran Hasyim Ashari - Mastrip - Gg. Hartono

Gambar 5 Hasil Simulasi Benley

Sumber: Hasil Analisa Benley 
Profile plot pada saluran yang berada di Jalan Pattimura Ki - P. Polim Ki - Dr. Sutomo. Banjir dimulai dari depan bengkel Suzuki (Jl. Pattimura) sampai Jalan Dr. Sutomo. Banjir yang terjadi disebabkan oleh saluran drainase yang tidak mampu menampung air limpasan dari hujan. Juga dikarenakan tidak sinkronnya pembangunan saluran yang masih mengikuti kontur jalan yang ada, sehingga terjadi kondisi saluran yang kurang baik, selain itu juga dikarenakan kondisi slope saluran yang sangat minim seperti di N2 - N10 sepanjang kurang lebih 1.100 meter hanya memiliki beda tinggi sebesar 0,50 meter.

Profile plot pada saluran yang berada di Jalan Rajekwesi - Untung Suropati - Dr. Sutomo. Genangan banjir terjadi dimulai di depan PDAM (Jl. Rajekwesi) sampai dengan jalan Dr. Sutomo. Banjir yang terjadi disebabkan oleh saluran drainase yang tidak mampu menampung air limpasan dari hujan. Serta kondisi slope saluran yang cenderung datar.

Profile plot pada saluran yang berada di Jalan Pattimura - Untung suropati Diponegoro. Genangan banjir terjadi dimulai di depan Puskesmas Wisma Indah (Jl. Pattimura) sampai dengan jalan Dr. Sutomo Banjir yang terjadi disebabkan oleh saluran drainase yang tidak mampu menampung air limpasan dari hujan. Serta kondisi slope saluran yang cenderung datar.

Profile plot pada saluran yang berada di Jalan PB. Sudirman - Hasannuddin. Banjir yang terjadi disebabkan oleh saluran drainase yang tidak mampu menampung air limpasan dari hujan. Juga dikarenakan tidak sinkronnya pembangunan saluran yang masih mengikuti kontur jalan yang ada sehingga terjadi kondisi saluran yang kurang baik,hal ini mengakibatkan terjadinya aliran yang tidak mampu mengalir atau mengurangi kapasitas debit eksisting saluran yang ada.

Profile plot pada saluran yang berada di Gg. Hartono - Mastrip - MH. Thamrin. Banjir yang terjadi disebabkan oleh saluran drainase yang tidak mampu menampung air limpasan dari hujan.

Profile plot pada saluran yang berada di Jalan Untung Suropati - Kyai Sulaiman Setyabudi - Hasanuddin - Gg Hartono. Saluran ini sepanjang 1.400 meter ,Banjir yang terjadi disebabkan oleh saluran drainase yang tidak mampu menampung air limpasan dari hujan. Juga dikarenakan tidak sinkronnya pembangunan saluran yang masih mengikuti kontur jalan yang ada sehingga terjadi kondisi saluran yang kurang baik.

Profile plot pada saluran yang berada di Jalan Hasyim Ashari - Mastrip - Gg. Hartono. Banjir yang terjadi disebabkan oleh saluran drainase yang tidak mampu menampung air limpasan dari hujan.

\section{Analisis Penanganan Genangan Kolam Retensi}

Rencana lokasi kolam retensi berada di sebelah Taman Rajekwesi dimana masih tersedia lahan yang cukup untuk dilakukan pembuatan kolam retensi. Daerah ini dipilih karena nantinya kolam retensi akan terintegrasi dengan Taman Rajekwesi dimana juga digunakan sebagai sarana hiburan atau hutan kota.

Direncanakan kedalaman Kolam Retensi adalah 2 meter, berdasarkan volume maksimum air limpasan sebesar $9.071,071 \mathrm{~m}^{3}$, maka $\mathrm{BL}=4.535,536 \mathrm{~m}^{3}$ dengan kemiringan lokasi sebesar $0,1 \%$ maka diperoleh nilai volume maksimum kolam retensi sebesar :

$$
\begin{aligned}
& \mathrm{Vt}=(\text { B.L.H })+(\text { 0,5.B.L.S }) \\
& =9.071,071+(0,5 \times 4.535,536 \times 0,1) \\
& =9.297,848 \mathrm{~m}^{3} \\
& \text { Dalam studi ini, direncanakan pompa } \\
& \text { yang akan dipakai disesuaikan dengan }
\end{aligned}
$$




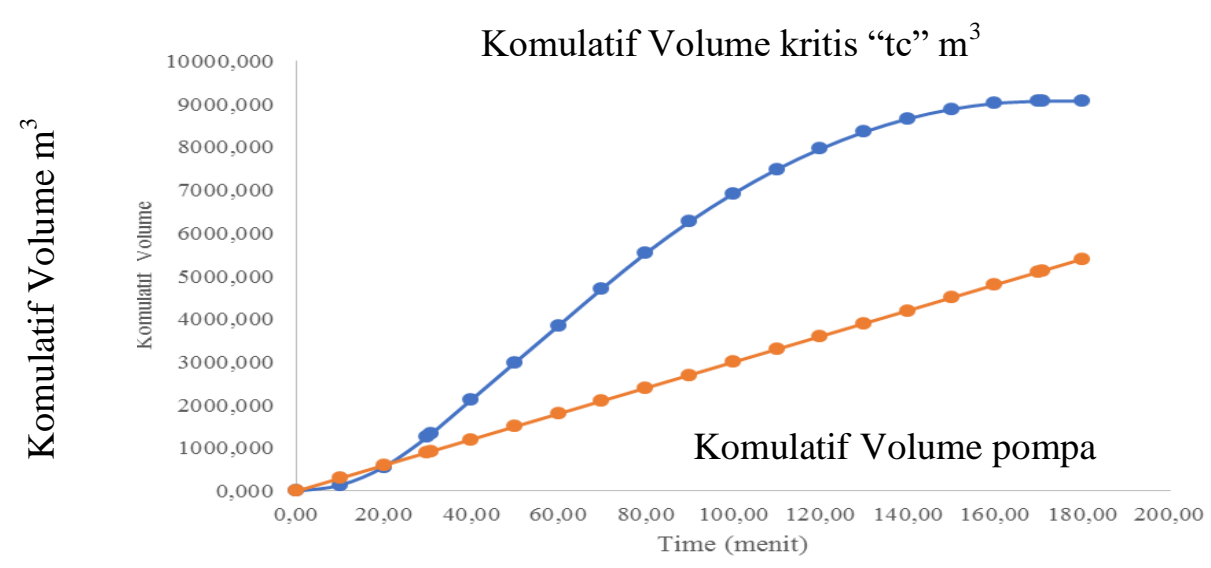

Gambar 5 Grafik Komulatif Aliran Kritis Dan Kapasitas Pompa

Sumber: Hasil Perhitungan

Dari hasil perhitungan didapat ketinggian air maksimum berada di menit ke 140 dengan ketinggian elevasi di kolam setinggi 0,892 meter dengan waktu pengosongan kolam selama 302,40 menit. Pola pengoperasian pompa dilakukan sebagaimana berikut :

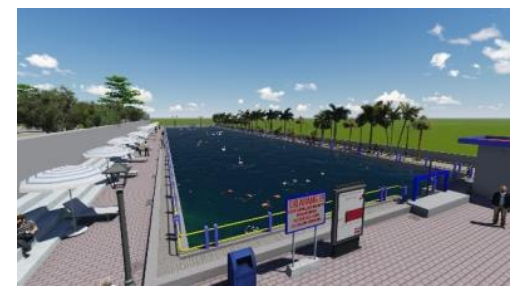

(a) Layout papan informasi

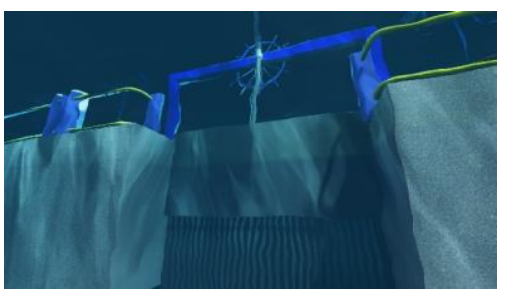

(c) trashrack inlet

\section{Sumur Resapan}

Perencanaan dimensi sumur resapan yang akan dibuat harus sesuai pada persyaratan teknis secara umum maupun khusus berdasarkan SNI No.03-2459-2002. Sumur resapan dipilih di lokasi yang merupakan daerah padat penduduk sehingga metode lain seperti kolam retensi tidak dapat dilakukan, dan lokasi dipilih berdasarkan potensi air masuk yang bisa menyebabkan banjir, sehingga ditentukan bahwa lokasi penanganan sumur resapan berada di Jl. Pattimura baik sebelah kanan maupun sebelah kiri.
1. Apabila terjadi hujan dan level muka air di kolam retensi melebihi normal.

2. Sesekali dilakukan operasi apabila digunakan untuk pemeliharaan bangunan kolam retensi

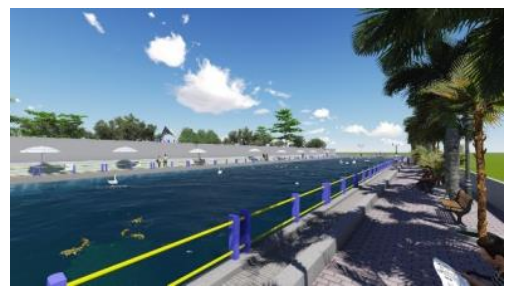

(b) layout item pendamping

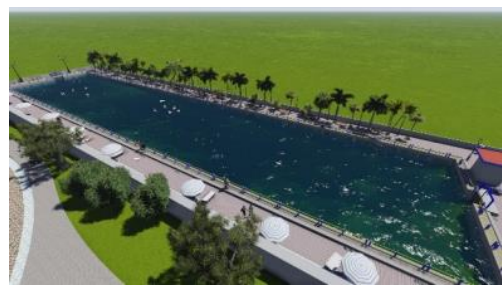

(d) tampak atas kolam

Sumur resapan direncanakan berbentuk segi empat dengan lebar 1,00 meter dan ketinggian 2,00 meter, dengan spesifikasi bangunan menggunakan SNI 03-24532002. Sumur resapan yang digunakan dimodifikasi dengan menggunakan rain barrel ukuran 750 liter, penggunaan rain barrel dilaksanakan karena memperhatikan luasan lahan di setiap rumah dan penggunaan air hujan yang dapat ditampung. Dengan metode tersebut maka air hujan tidak hanya diresapkan ke dalam tanah tetapi juga dapat dimanfaatkan secara gravitasi. Banyaknya sumur yang 
direncanakan untuk mereduksi genangan di lokasi studi sejumlah 577 unit, dengan lokasi di Jl. Pattimura sebelah kanan (wisma indah baru ) sejumlah 179 buah dan Jl. Pattimura sebelah kiri (Wisma Indah) sebanyak 398 Unit. Nilai reduksi dedbit yang didapat dengan pengapilkasian metode kombinasi antara sumur resapan dengan ukuran lebar 1,00 meter dan ketinggian 2,00 meter yang digabung menggunakan rain barrel kapasitas 750 liter adalah sebesar 32,25 sampai dengan 35,66 prosen.

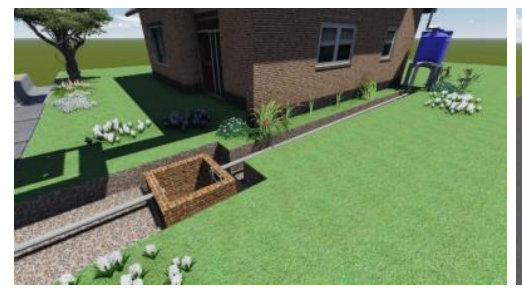

a. Jaringan pipa resapan

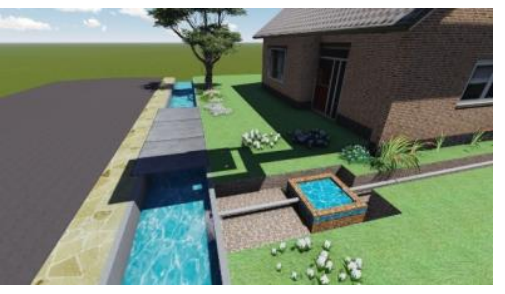

b. Jaringan sumur resapan

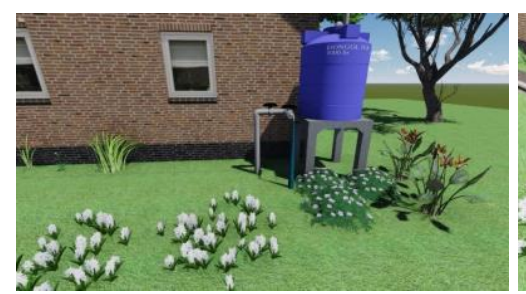

c. Tandon kapasitas 750 ltr

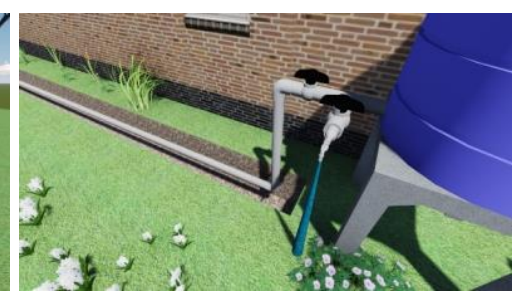

d. Stop kran air tandon

Gambar 6 Layout 3D Simulasi Sumur Resapan Sumber: Hasil Desain Sumur Resapan

\section{Modifikasi Saluran}

Pelebaran saluran berakibat kepada terambil sebagian lahan di sekitar saluran. Hal tersebut berarti mempersempit badan jalan. Penambahan kedalaman saluran juga harus memperhatikan volume galian yang harus terutama kemiringan saluran (Suripin : 2004), dengan dimensi saluran segiempat yang ekonomis adalah saluran yang lebar salurannya dua kali kedalaman maksimumnya. Modifikasi saluran dilaksanakan di tiga ruas jalan, meliputi Jl. Panglima Polim, Jl. Dr. Sutomo dan Jl. Diponegoro dimana dalam memodifikasi saluran hanya akan dilakukan pelebaran karena tidak memungkinkan untuk dilakukan pendalaman dikarenakan kemiringan saluran yang datar. Saluran tersebut nantinya

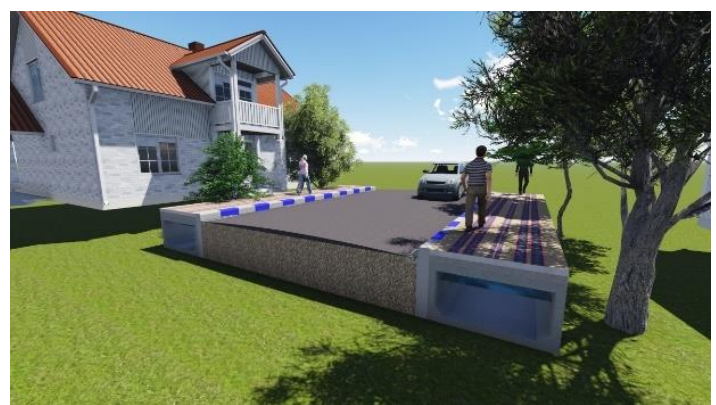

akan dibuat menggunakan ferrocement dengan dilengkapi trotoar berupa paving blok diatas saluran dilengkapi pula dengan manhole sehingga normalisasi serta perawatan saluran nantinya tetap dapat dilaksanakan, untuk $\mathrm{Jl}$. Panglima Polim sepanjang 249 meter akan dimodifikasi dengan lebar 1,60 meter, Jl. Dr. Sutomo sepanjang 411 meter akan dimodifikasi dengan lebar 1,60 meter, dan Jl. Diponegoro sepanjang 393 meter juga akan dimodifikasi dengan lebar 1,60 meter. Perbaikan / modifikasi saluran yang meluap akan dilakukan simulasi ulang menggunakan software Bentley Sewergems Connect bentuk konstruksi saluran dapat dilihat pada Gambar 7 dibawah ini :

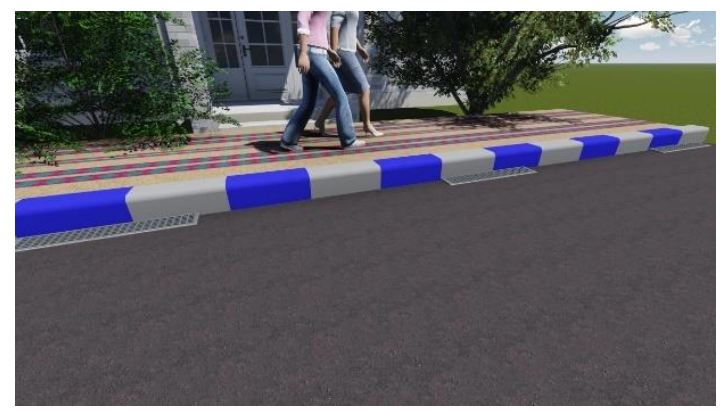

Gambar 7 Rencana Desain Modifikasi Saluran Drainase Eksisting 


\section{Rencana Anggaran Biaya}

Total biaya yang diperlukan guna penyelesaian permasalahan genangan dilakukan dengan berbagai upaya penanganan antara lain berupa pembuatan kolam retensi, sumur resapan dan juga modifikasi saluran. Dimana kombinasi 3 metode diatas membutuhkan biaya sebesar

Rp. 12.955.758.000 (dua belas milyar sembilan ratus lima puluh lima juta tujuh ratus lima puluh delapan ribu rupiah ). Dengan biaya untuk masing-masing pekerjaan Kolam retensi sebesar Rp 5. 413.658.000,00, Sumur resapan sebesar Rp. 2.767.146.000,00 dan modifikasi saluran sebesar Rp. 12.955.758.000,00

\section{KESIMPULAN DAN SARAN Kesimpulan}

Dari hasil perhitungan dan analisa yang telah dilakukan, maka dapat ditarik kesimpulan sebagaimana berikut:

1. Gambaran di lokasi studi yang menyebabkan banjir setelah dilakukan analisa dikarenakan lokasi daerah studi yang cenderung datar/flat sehingga tidak mampu mengalirkan air secepat-cepatnya menuju badan air. Serta tidak mampunya saluran drainase menampung limpasan air hujan dengan debit direncanakan Q5th. Terdapat 12 lokasi setelah dilakukan analisa mengalami luapan/genangan antara lain berada saluran drainase di ruas Jalan Pattimura, Untung Suropati, Ade Irma Suryani, Dr. Sutomo, Panglima Polim, Setyabudi, Mastrip, Panglima Besar Sudirman, Agus Salim, Diponegoro, Gajahmada, serta Kyai Sulaiman. Kedalaman genangan di 12 ruas jalan tersebut rerata sebesar $119,4 \%$ Dengan kedalaman maksimum tertinggi berada di jalan Panglima Polim sebesar 138,70 \%.

2. Alternatif penanggulangan genangan yang berbasis konservasi air yang dilakukan pada lokasi studi adalah sebagai berikut :

a. Kolam retensi ditetapkan di lokasi jalan rajekwesi dengan pertimbangan berkontribusi melimpaskan air hujan penyebab banjir di bagian hilir. kolam retensi didesain berdampingan dengan taman rajekwesi sehingga pemanfaatannya bisa digunakan juga sebagai sarana wisata, kolam retensi nantinya dilengkapi satu pintu inlet serta pompa dengan kapasitas yang telah direncanakan adapun data teknis dari perencanaan kolam retensi adalah

sebagai berikut :

- Panjang x lebar $\quad=100 \times 50 \mathrm{~m}$

- Kedalaman rencana $=1,86 \mathrm{~m}$

- Tinggi Jagaan $\quad=1,00 \mathrm{~m}$

- Tinggi total $\quad=2,86 \mathrm{~m}$

- Volume total $\quad=9.297 \mathrm{~m}^{3}$

- Kapasitas pompa $\quad=0,5 \mathrm{~m}^{3} / \mathrm{dtk}$

(outflow)

- Debit inflow $\quad=0,97 \mathrm{~m}^{3} / \mathrm{dtk}$

- Saluran inlet $(\mathrm{BxH}) \quad=1,00 \times 1,00 \mathrm{~m}$

b. Sumur resapan ditetapkan dilokasi perumahan padat penduduk di Jl. Pattimura dimana direncanakan berjumlah 577 bh dengan asumsi setiap rumah menerapkan metode ini, lokasi ini memiliki nilai koefisien permeabilitas (K) sebesar $0,73 \mathrm{~m} /$ hari (lempung kelanauan) dengan kedalaman air tanah sumur dangkal warga pada kondisi musim hujan setinggi 2,00 meter, maka sumur resapan didesain dengan rencana menggunakan bentuk segi empat dengan dimensi P x L x T adalah $1,00 \times 1,00 \times$ $2,00 \mathrm{~m}$ dan dikombinasikan dengan box detensi menggunakan tandon air dengan volume $0,75 \mathrm{~m}^{3}$. Dengan desain diatas maka diperoleh nilai reduksi limpasan air hujan yang masuk ke sistem berkisar antara $32-35 \%$

c. Modifikasi saluran dilakukan disaluran yang tidak memungkinkan dilakukan metode menggunakan metode konservasi air sehingga dilakukan metode konvensional dengan melakukan redimensi saluran, lokasi yang dipilih untuk dilakukan modifikasi saluran berada di Jalan Panglima Polim dirubah menjadi 1,60 meter sepanjang 249,00 meter, Jalan Dr. Sutomo dimensi rencana menjadi lebar 1,60 meter sepanjang 411,00 meter, Jalan Diponegoro dimensi rencana menjadi lebar 1,60 meter sepanjang 393,00 meter

3. Anggaran biaya yang diperlukan untuk menanggulangi permasalahan genangan yang terjadi di lokasi studi adalah sebesar Rp. 12.955.758.000,00 (dua belas milyar sembilan ratus lima puluh lima juta tujuh ratus lima puluh delapan ribu rupiah)

\section{Saran}

Dari hasil perhitungan dan analisa yang telah dilakukan, maka ada beberapa saran sebagai berikut: 
1. Peningkatan limpasan permukaan yang terjadi dapat dikendalikan dengan cara penerapan pola tata ruang yang berwawasan lingkungan, sehingga diharapkan pola pengembangan kawasan di daerah yang berkembang juga memperhatikan kawasan hijau atau resapan.

2. Peran serta masyarakat sangat dibutuhkan salah satunya adalah perluasan daerah resapan sesuai dengan ketentuan $60 \%$ dari persil bangunan, sehingga limpasan yang masuk ke badan air bisa dikurangi.

3. Untuk penelitian selanjutnya perlu dilakukan kompirasi menggunakan metode /software lain sehingga diperoleh data pembanding untuk meningkatkan keakuratan hasil yang dicapai.

\section{DAFTAR PUSTAKA}

Bisri dan Prastya. 2009. Imbuhan Air Tanah Buatan Untuk Mereduksi Genangan
(Studi Kasus di Kecamatan Batu Kota Batu). Jurnal Rekayasa Sipil Volume 3 Nomor 1

Bagian Pembangunan Kabupaten Bojonegoro, 2017. Standart upah Kerja dan Bahan Bangunan Kabupaten Bojonegoro Tahun 2017. Bagian Pembangunan Kabupaten Bojonegoro, Bojonegoro.

Departemen Pekerjaan Umum, 2010. Buku Panduan Sistem Drainase Mandiri Berbasis Masyarakat yang Berwawasan Lingkungan (Tata cara Pembuatan Kolam Retensi dan Polder). Departemen Pekerjaan Umum Direktorat Jenderal Cipta Karya. Jakarta

Kusnaedi, 1995, Sumur Resapan Untuk Pemukiman dan Perkecamatanan, Penerbit Swadaya, Jakarta

Suyono Sosrodarsono, 2003, Hidrologi Untuk Pengairan, Pradnya Paramita, Jakarta. 